\title{
Henckelia umbellata (Gesneriaceae), a new species from the eastern Himalaya of India
}

\author{
Kanthraj A.S., Rana T.S. \& K.N. Nair* \\ Plant Diversity, Systematics and Herbarium Division, CSIR-National Botanical Research Institute, \\ Rana Pratap Marg, Lucknow, Uttar Pradesh - 226 001, India. \\ *E-mail: knnair@nbri.res.in
}

\begin{abstract}
A new species of Henckelia, H. umbellata is described from Arunachal Pradesh, India. H. umbellata sp. nov. can be easily distinguished by its umbellate inflorescence from other congeners. It superficially resembles H. longisepala (H.W.Li) D.J.Middleton \& Mich.Möller in the large paired involucral bracts enclosing the flowers. It also shows similarity with $H$. urticifolia (Buch.-Ham. ex D.Don) A.Dietr. in habit, presence of glandular trichomes inside the corolla tube and glabrous ovary but several other characters are distinct between the species. A detailed description of the new species along with colour photographs, distribution, affinities and comparison with related species is given.
\end{abstract}

Keywords: Arunachal Pradesh, Didymocarpoideae, Gesneriaceae, Henckelia, New species.

\section{Introduction}

The genus Henckelia Spreng. currently includes $c$. 70 species of perennial, caulescent or scapigerous or rarely creeping herbs, distributed in Sri Lanka, India, Bangladesh, Nepal, Bhutan, S China, Myanmar, N Vietnam, N Laos, and N Thailand (Möller et al., 2017; Krishna \& Lakshminarasimhan, 2018; Borah et al., 2019; Cai et al., 2019; Sirimongkol et al., 2019; Yang et al., 2019). Henckelia was redefined by the inclusion of species formerly placed in Didymocarpus Wall. sect. Orthoboea Benth., Chirita Buch-Ham. ex D.Don sect. Chirita, and the monotypic Hemiboeopsis Wang (Weber \& Burtt, 1998[“1997”]; Weber et al., 2011; Middleton et al.,

Received: 21.12.2019; Revised \& Accepted: 26.03 .2020

Published Online: 11.05 .2020
2013). The re-circumscribed Henckelia is characterized predominantly by a chiritoid stigma and plagiocarpic or orthocarpic capsules (Möller et al., 2017).

In India, Henckelia is represented by 35 species, including the five recently described species $H$. pradeepiana Nampy, Manudev \& A.Weber (Manudev et al., 2012), H. sivagiriensis (Rajakumar, Selvak., S.Murug. \& Chellap.) E.S.S.Kumar (Kumar, 2014), H. bracteata Janeesha \& Nampy (2015), $H$. pathakii G.Krishna \& Lakshminarasimhan (2018), H. collegii-sancti-thomasii A.Joe, D.Borah, Taram \& Sandhya (Borah et al., 2019), and a new species described by Janeesha and Nampy (this issue). Möller et al., (2017) grouped the Indian species of Henckelia in two groups: (i) species previously placed in Chirita sect. Chirita, with a caulescent habit with internodes and leaves in whorls of 2 or 3 and orthocarpic capsules-19 species in W and E Himalayas and NE India; (ii) species corresponding to Henckelia sect. Henckelia (Weber \& Burtt, 1998[“1997”]), characterised by scapigerous habit with leaves in basal rosette and plagiocarpic capsules-16 species mostly in S Western Ghats, of which 15 are endemic and one species, $H$. humboldtiana (Gardner) Weber \& Burtt, has a distribution which extends into Sri Lanka (Ranasinghe et al., 2016).

During recent plant explorations in 2018 and 2019, one of the authors (KAS) collected some gesneriad specimens from Lower Subansiri, Kra Daadi and Kurung Kumey districts of Arunachal Pradesh in India. Further comparative studies with relevant 
specimens available in ASSAM, BSD, BSHC, CAL, CALI, DD, FRC, LWG, MH \& TBGT and digital specimen images accessed from virtual herbaria of BM, E, G, K, L, P \& W and taxonomic literature (Don, 1822, 1825; Candolle, 1845; Clarke, 1874, 1883, 1885[“1884”]; Wood, 1974; Li, 1983; Wang et al., 1998; Sinha \& Datta, 2016) revealed that the new collections represented a hitherto undescribed species of Henckelia and is described here as new.

Henckelia umbellata Kanthraj \& K.N.Nair, sp. nov.

Fig. 1

The new species can be easily distinguished from its congeners by its flowers borne in umbels. H. umbellata superficially resembles $H$. longisepala (H.W.Li) D.J.Middleton \& Mich.Möller mainly in the large paired involucral bracts enclosing the flowers. But it differs from $H$. longisepala in having 4-6-flowered umbellate inflorescences ( $v s$. 3-9-flowered umbel-like cymes); fused, narrowly triangular, acuminate sepals (vs. free, spatulate-linear, obtuse sepals) and anther connective without any appendage ( $v s$. connective with one appendage abaxially).

Type: INDIA, Arunachal Pradesh, Kra Daadi district, near Yangte village, $27^{\circ} 44^{\prime} 7.23 " \mathrm{~N}, 93^{\circ} 38^{\prime} 8.18^{\prime \prime} \mathrm{E}$, 1295 m, 12.09.2018, A.S. Kanthraj 319888 (holo LWG!; iso CAL!).

Perennial caulescent herbs. Stems erect to sometimes decumbent, 30-150 cm long, scarcely branched, rooting from the woody base, internodes 6.5-11 cm long, cylindrical, green to dark purplishbrown, indumentum white with reddish-brown tips. Leaves opposite, usually in unequal pairs with a large and a slightly smaller leaf; petioles $3-11 \mathrm{~cm}$ long, 1-3 mm broad, green-brownish, sparsely hairy with red-brown hairs; lamina ovate to ellipticoblong, 8-18 × 4-8 cm, apex acuminate, margins crenate-serrate, densely brown pubescent, base oblique, upper surface with many white pilose hairs, lower surface with white and reddish-brown pilose hairs and many white sessile glands; lateral veins 8-12 pairs, more prominent and clothed with redbrown hairs on lower surface. Inflorescence axillary, umbellate, 4-6-flowered; peduncles 3-6 cm long, stout, terete, green to dark purple, densely hairy; bracts 2, free, enclosing the flower buds, broadly ovate, $2.8-3.5 \times 2.4-2.6 \mathrm{~cm}$, apex acuminate, shallowly crenate towards apex, green with prominent purplish veins, with brown hairs outside, glabrous inside, caducous; pedicels enclosed within the bracts, $1.2-2.2 \mathrm{~cm}$ long, stout, greenish-white, glabrous. Calyx 5-lobed, fused almost up to middle, $3.5-3.7 \mathrm{~cm}$ long, purplish-white; tube $1.7-2.0 \mathrm{~cm}$; lobes narrowly triangular, $1.7-1.8 \mathrm{~cm}$ long, acuminate, white pilose hairy outside, glabrous inside. Corolla infundibuliform, 5-7 cm long, tube slightly curved downward, bluish purple, abruptly tapering towards the whitish base, sparsely hairy out, bilabiate, 5-lobed, lower lobes 3, 0.8-1.2 ×1.0$1.4 \mathrm{~cm}$, upper lobes $2,1.0-1.5 \times 1.5-1.8 \mathrm{~cm}$; lobes entire, rounded, bluish purple, throat with yellow, purple markings and dark purple-brown stripes, inner surface with many glandular trichomes. Stamens 2; filaments inserted c. $2.5 \mathrm{~cm}$ above the base of the corolla, 1.0-1.2 cm long, geniculate, white, sometimes with yellow marking at geniculation, clothed with a tuft of glandular hairs near the connective and below the geniculation; anthers coherent face to face, $2.5-4 \times 1.5-2.2 \mathrm{~mm}$, creamy with a purple blotch, glabrous. Staminodes 2 , on either side of the stamen, inserted c. $2 \mathrm{~cm}$ from base of the corolla, c. $1 \mathrm{~cm}$ long, whitish, sparsely hairy, antherodes incurved, greenish, glabrous. Disc tubular, c. $7 \mathrm{~mm}$ high, shallowly 5lobed, greenish; ovary 20-23 × 1.5-2 mm, green, glabrous; style 1.2-1.5 cm long, whitish, glandular pubescent; stigma upper lip absent or very obscure, lower lip deeply bilobed, 3-3.5 mm long, 4.5-7 mm wide, papillose, purplish-white. Capsules 10$16.5 \mathrm{~cm}$ long, linear, green, orthocarpic, without persistent disc and calyx. Seeds broadly ellipsoid, 0.4-0.47 × 0.18-0.23 mm, dark brown, pitted.

Flowering \& fruiting: Flowering from August to October and fruiting from September to November.

Habitat: On muddy slopes and shady places along moist tropical forest margins at elevation of 770 to $1700 \mathrm{~m}$. The species occurs sporadically in small patchy populations with a few to many plants. 

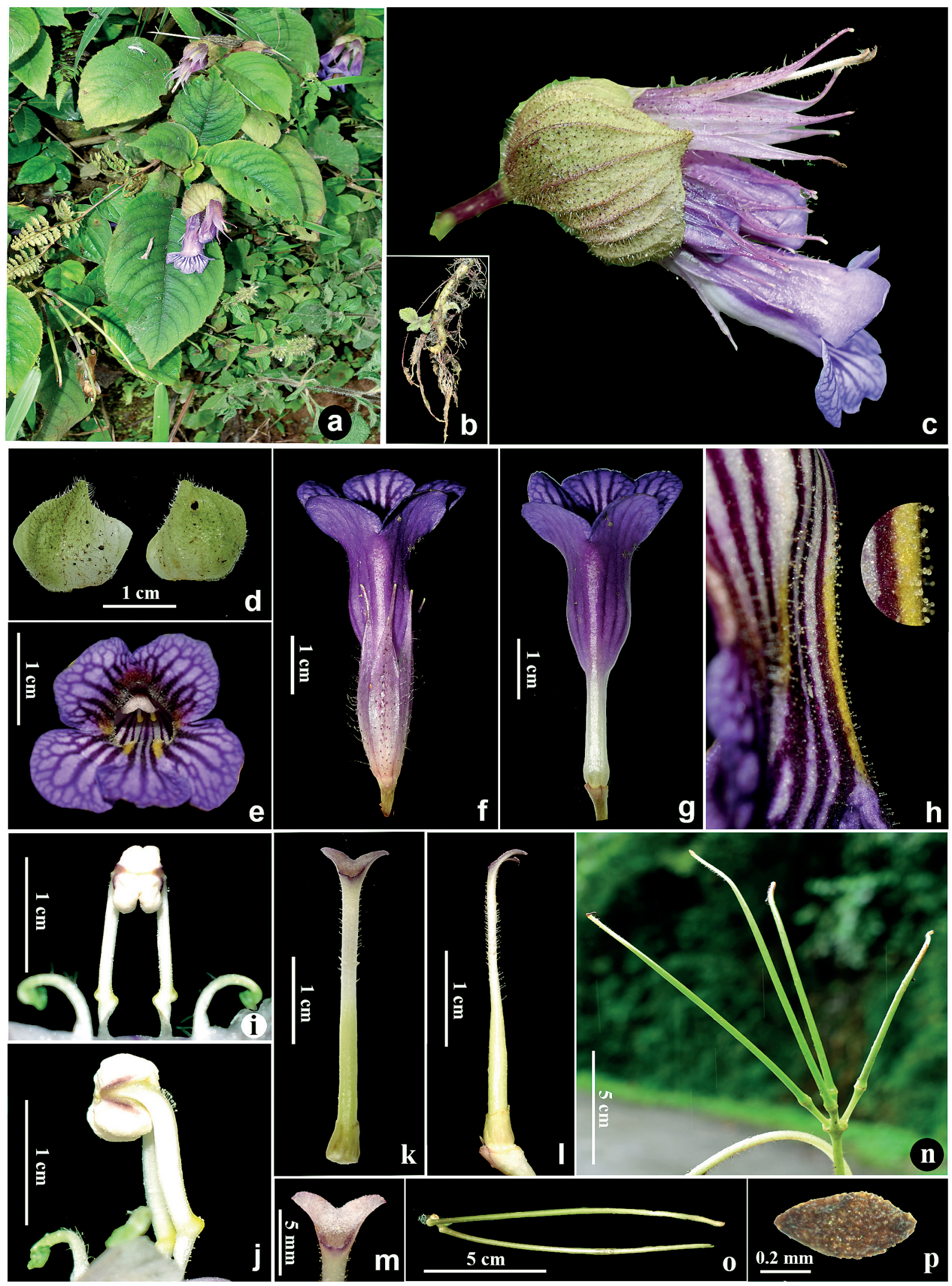

Fig. 1. Henckelia umbellata Kanthraj \& K.N.Nair: a. Habit; b. New shoot sprouting from the base of an adult plant; c. Umbellate inflorescence with large bracts; d. Bracts; e. Flower-front view; f. Flower-ventral view; g. Flower-ventral view, calyx removed; h. Glandular trichomes on inner surface of corolla; i \& j. Stamens and staminodes-i. Ventral view; j. Side view; k. \& I. Pistil- k. Front view; I. Side view; m. Chiritoid stigma; n. Infructescence with young capsules; 0. Mature capsules; p. Seed (images by A.S. Kanthraj). 
Distribution: So far known only from Arunachal Pradesh, India (Fig. 2).

Etymology: The specific epithet denotes the characteristic umbellate inflorescence of this species.

Specimens examined: INDIA, Arunachal Pradesh, Kra Daadi district, near Choba village, $\mathrm{N}$ 27²5'30.6", E 93³6’36.72", 1003 m, 12.09.2018, A.S. Kanthraj 319892; near Yangte village, N 27²4'2.63", E 9338'15.04", 1288 m, 19.09.2019, A.S. Kanthraj 321076; Palin-Nyapin, near Yangte village, N 2744'8.08", E 93³8'7.37", 1286 m, 12.09.2018, A.S. Kanthraj 319890 (LWG); Kurung Kumey district, $15 \mathrm{~km}$ before Koloriang town, N 2752'39.05", E 9326'59.67", 772 m, 19.09.2019, A.S. Kanthraj 321087; Koloriang, N 2754'12.13", E 93²2'29.27", 843 m, 20.09.2019, A.S. Kanthraj 321088; Yarte, N 2754'12.13", E 93 22'29.27", 793 m, 19.09.2019, A.S. Kanthraj 321085 (LWG);
Lower Subansiri district, near Deed, N 27³3'30.63", E 9341'8.16", 1579 m, 18.09.2019, A.S. Kanthraj 321074; New Palin to Deed, N 27³8'53.88", E 9337'36.48", 1310 m, 13.09.2018, A.S. Kanthraj 319893; Ziro, N 27³2'28.91", E 9347'35.99", 1695 m, 21.09.2019, A.S. Kanthraj 321089 (LWG).

Conservation status: The species has so far been found at seven localities in three districts in Arunachal Pradesh. Preliminary surveys revealed that the species occurs in small fragmented populations, each with four to fifteen mature individuals. The expansion of the National Highway 713, which connects Joram and Koloriang via Palin in Arunachal Pradesh, is a potential threat to the natural habitat and populations of this species. Further surveys and studies in other likely areas of its occurrence are needed to assess the conservation

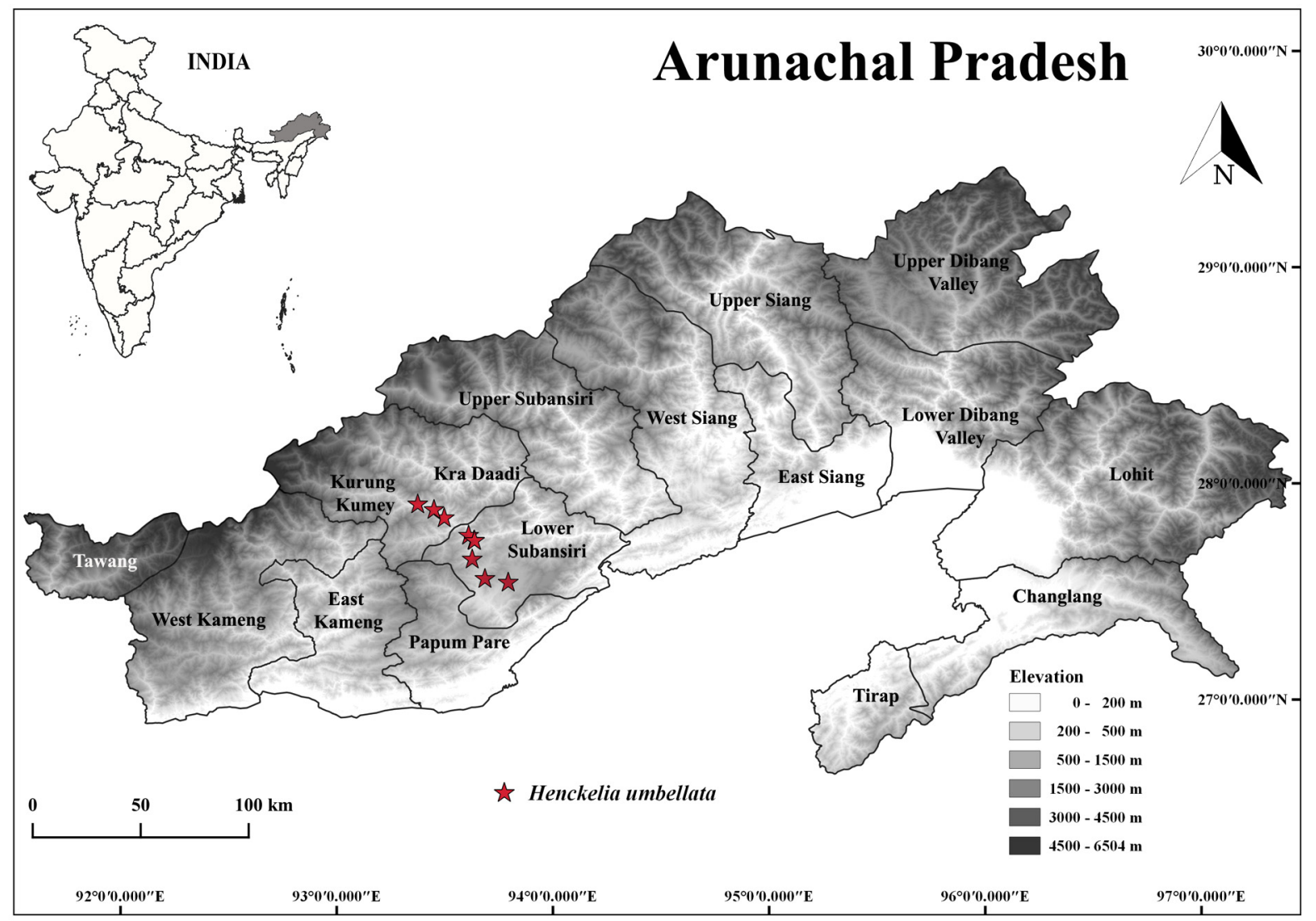

Fig. 2. Map showing the collection sites of Henckelia umbellata Kanthraj \& K.N.Nair in Arunachal Pradesh, India [drawn using the software QGIS 3.8.2 Zanzibar (QGIS Development Team, 2019)]. 
Table 1. Comparison of selected morphological characters in Henckelia umbellata, H. longisepala, and H. urticifolia

\begin{tabular}{|c|c|c|c|}
\hline Characters & $\begin{array}{l}\text { H. umbellata Kanthraj } \\
\text { \& K.N.Nair }\end{array}$ & $\begin{array}{l}\text { H. longisepala (H.W.Li) } \\
\text { D.J.Middleton \& Mich.Möller }\end{array}$ & $\begin{array}{l}\text { H. urticifolia (Buch.-Ham. } \\
\text { ex D.Don) A.Dietr. }\end{array}$ \\
\hline Habit & $\begin{array}{l}\text { Erect or sometimes } \\
\text { decumbent herbs }\end{array}$ & Erect or decumbent subshrubs & Decumbent herbs \\
\hline Leaves & $\begin{array}{l}\text { Broadly ovate to elliptic-oblong, } \\
8-18 \times 4-8 \mathrm{~cm}, \text { margins } \\
\text { crenate-serrate }\end{array}$ & $\begin{array}{l}\text { Ovate to oblong-oblanceolate, } \\
\text { falcate, } 9-24 \times 3-6.5 \mathrm{~cm} \text {, margins } \\
\text { repand-crenulate to nearly entire }\end{array}$ & $\begin{array}{l}\text { Ovate to elliptic-oblong, } \\
4-12 \times 3.5-7.5 \mathrm{~cm}, \text { margins } \\
\text { crenate-serrate }\end{array}$ \\
\hline Inflorescence & 4-6-flowered umbels & 3-9-flowered umbellate cymes & 1-3-flowered cymes \\
\hline Bracts & $\begin{array}{l}\text { Broadly ovate, } 2.8-3.5 \times \\
2.4-2.6 \mathrm{~cm} \text {, at base of the } \\
\text { pedicel, enveloping the flowers, } \\
\text { green }\end{array}$ & $\begin{array}{l}\text { Ovate-orbicular, } c .2 \times 2.5 \mathrm{~cm} \text {, } \\
\text { at the base of pedicel, enveloping } \\
\text { the flowers, purplish white to dark } \\
\text { purple }\end{array}$ & $\begin{array}{l}\text { Ovate-lanceolate, } 0.8-2 \times \\
0.5-1.5 \mathrm{~cm} \text {, at base of the } \\
\text { pedicel, not enveloping the } \\
\text { flowers, green }\end{array}$ \\
\hline Sepals & $\begin{array}{l}\text { Fused almost up to middle, } \\
\text { narrowly triangular, acuminate } \\
\text { at apex }\end{array}$ & $\begin{array}{l}\text { Free from base, spatulate-linear, } \\
\text { obtuse at apex }\end{array}$ & $\begin{array}{l}\text { Fused almost up to middle, } \\
\text { triangular, long-acuminate } \\
\text { at apex, often deflexed }\end{array}$ \\
\hline $\begin{array}{l}\text { Colour of } \\
\text { corolla lobes }\end{array}$ & Bluish-purple & Purplish to white & Pinkish to red purple \\
\hline $\begin{array}{l}\text { Staminal } \\
\text { filaments }\end{array}$ & $\begin{array}{l}\text { Geniculate with a tuft of } \\
\text { glandular hairs at apex and } \\
\text { a few at base }\end{array}$ & $\begin{array}{l}\text { Geniculate, glabrous to puberulent } \\
\text { near apex }\end{array}$ & $\begin{array}{l}\text { Geniculate, glabrous to } \\
\text { glandular hairy, often with } \\
\text { sessile glands }\end{array}$ \\
\hline Anthers & $\begin{array}{l}\text { Connective without any } \\
\text { appendage }\end{array}$ & $\begin{array}{l}\text { Connective with one appendage } \\
\text { abaxially }\end{array}$ & $\begin{array}{l}\text { Connective without any } \\
\text { appendage }\end{array}$ \\
\hline Disc & Tubular, c. $7 \mathrm{~mm}$ high, greenish & Annular, c. $2 \mathrm{~mm}$ high, purplish & Tubular, c. $5 \mathrm{~mm}$ high, yellow \\
\hline Ovary & Glabrous, without sessile glands & Glabrous, without sessile glands & $\begin{array}{l}\text { Glabrous, often with } \\
\text { sessile glands }\end{array}$ \\
\hline Style & Glandular pubescent & Glandular puberulent & $\begin{array}{l}\text { Glandular and eglandular } \\
\text { pubescent }\end{array}$ \\
\hline
\end{tabular}

`Based on descriptions provided by Li (1983), Wang et al. (1998) and Bui et al. (this issue).

status of the new species. Based on the present data, it is provisionally assessed here as "Data Deficient (DD)" under the IUCN Red List Categories and Criteria (version 3.1) (IUCN 2001, 2012, 2019).

Notes: Henckelia umbellata belongs to the group of NE Indian and Himalayan species of Henckelia with caulescent habit, internodes with leaves in whorls of 2 or 3, and orthocarpic capsules. H. longisepala with which $H$. umbellata shares morphological similarities has an isolated geographic distribution in China and Laos (Li, 1983; Wang, 1984; Wang et al., 1988; Weber et al., 2011) and in Vietnam (Bui et al., this issue). Although H. umbellata shows resemblances with $H$. longispepala and $H$. urticifolia, its true phylogenetic affinities with other congeners need to be examined further (see Table 1).

\section{Acknowledgements}

The authors wish to express their sincere thanks to the Department of Forests and Wildlife, Government of Arunachal Pradesh for granting permission and providing logistics support to conduct plant surveys and collections in the forest areas of Arunachal Pradesh; Curators of ASSAM, BM, BSD, BSHC, CAL, CALI, DD, E, FRC, G, $\mathrm{K}, \mathrm{L}, \mathrm{LWG}, \mathrm{MH}, \mathrm{P}, \mathrm{TBGT} \& \mathrm{~W}$ for having permitted to consult the herbarium specimens and access digital images of Henckelia; Director, CSIRNational Botanical Research Institute, Lucknow for facilities; and to Science and Engineering Research Board (SERB), Government of India for financial support under Plant Sciences scheme (EMR/2014/ 
000271). The authors also thank the editor Dr Michael Möller and two anonymous reviewers for their constructive comments on the manuscript.

NBRI Communication Number: CSIR-NBRI_MS/ 2019/12/09

\section{Literature Cited}

BORAH D., TARAM M., JOE A. \& S.V. NEELAMKAVIL 2019. Henckelia collegii-sancti-thomasii: a new species of Henckelia (Gesneriaceae) from Northeastern India. Phytotaxa 415(4): 247-251. https://dx.doi.org/10.11646/ phytotaxa.415.4.10

BUI H.Q., NURALIEV M.S., MÖLLER M., KUZNETSOV A.N., KUZNETSOVA S.P, MIDDLETON D.J. \& F. WEN 2020. Henckelia longisepala (Gesneriaceae), a new record for Vietnam. Rheedea this issue. https://dx.doi.org/10.22244/ rheedea.2020.30.01.12

CAI L., LIU D.T., ZHANG P. \& Z.L. DAO 2019. Two new species of Henckelia (Gesneriaceae) from South eastern Yunnan, China. PhytoKeys 130: 151-160. https:/ /doi.org/10.3897/phytokeys.130.33988

CANDOLLE DE A.P. 1845. Cyrtandraceae. In: CANDOLLE DE A. (ed.), Prodromus systematis naturalis regni vegetabilis. Volume 9. Treuttel et Wurtz, Paris. pp. 258-286.

CLARKE C.B. 1874. Commelynaceae et Cyrtandraceae Bengalenses. Thacker, Spink \& Co., Calcutta. pp. 1-135.

CLARKE C.B. 1883. Cyrtandreae. In: DE CANDOLLE A. \& C. DE CANDOLLE (eds.), Monographiae Phanerogamarum Prodromi. Volume 5(1). G. Masson, Paris. pp. 1-303.

CLARKE C.B. 1885 [“1884”]. Gesneriaceae. In: HOOKER J.D. (ed.), The Flora of British India. Volume 4. L. Reeve \& Co., London. pp. 336-375.

DON D. 1822. Descriptions of two new genera of Nepaul plants. Edinburgh Philosophical Journal 7(13): 82-86.

DON D. 1825. Didymocarpae. In: DON D. (ed.), Prodromus Florae Nepalensis. J. Gale, London. pp. 121-124.

IUCN 2001. IUCN Red List Categories and Criteria. Version 3.1. IUCN Species Survival Commission. IUCN, Gland, Switzerland and Cambridge, U.K.

IUCN 2012. IUCN Red List Categories and Criteria. Version 3.1. Second edition. IUCN, Gland, Switzerland and Cambridge, UK.

IUCN Standards and Petitions Committee 2019. Guidelines for Using the IUCN Red List Categories and Criteria. Version 14. Prepared by the Standards and Petitions
Committee. Downloadable from: http://www. iucnredlist.org/documents/RedListGuidelines.pdf

JANEESHA A.P. \& S. NAMPY 2015. Henckelia bracteata, a new species of Gesneriaceae from southern Western Ghats, India, and lectotypification of Didymocarpus humboldtianus (H. humboldtiana). Willdenowia 45(1): 5359. https://doi.org/10.3372/wi.45.45105

JANEESHA A.P. \& S. NAMPY 2020. A taxonomic revision of Henckelia (Gesneriaceae) in South India with one new species and seven lectotypifications. Rheedea this issue. https://dx.doi.org/10.22244/rheedea.2020.30.01.03

KRISHNA G. \& P. LAKSHMINARASIMHAN 2018. A new species of Henckelia (Gesneriaceae) from Arunachal Pradesh, India. Taiwania 63(4): 397-401. https://doi.org/10.6165/tai.2018.63.397

KUMAR E.S.S. 2014. A new combination in Henckelia (Gesneriaceae). Polish Botanical Journal 59(1): 149. https:/ /doi.org/10.2478/pbj-2014-0002

LI H.W. 1983. Notulae Gesneraceis Yunnanensibus. Bulletin of Botanical Research, Harbin 3(2): 1-3.

MANUDEV K.M., WEBER A. \& S. NAMPY 2012. Henckelia pradeepiana, a new species of Gesneriaceae from the southern Western Ghats, India. Rheedea 22(2): 119-123.

MIDDLETON D.J., WEBER A., YAO T.L., SONTAG S. \& M. MÖLLER 2013. The current status of the species hitherto assigned to Henckelia (Gesneriaceae). Edinburgh Journal of Botany 70(3): 385-404. https://doi.org/ 10.1017/S0960428613000127

MÖLLER M., NAMPY S., JANEESHA A.P. \& A. WEBER 2017. The Gesneriaceae of India: Consequences of updated generic concepts and new family classification. Rheedea 27(1): 23-41. https://dx.doi.org/10.22244/ rheedea.2017.27.1.5

QGIS DEVELOPMENT TEAM 2019. QGIS Geographic Information System. QGIS 3.8.2- Zanzibar. Open Source Geospatial Foundation Project. Available at: http://qgis.osgeo.org

RANASINGHE S., MILNE R., JAYASEKARA R., RUBASINGHE S. \& M. MÖLLER 2016. Henckelia wijesundarae, a new endemic species from Sri Lanka, and lectotypification of Chirita walkerae and C. walkerae var. parviflora. Willdenowia 46(2): 213-224. https://doi.org/ 10.3372/wi.46.46202

SINHA B.K. \& S. DATTA 2016. Taxonomic account on the family Gesneriaceae in Northeast India. Nelumbo 58: 1-43. https://doi.org/10.20324/nelumbo/v58/2016/ 105932

SIRIMONGKOL S., PARNEL J.A.N., HODKINSON T.R., MIDDLETON D.J. \& C. PUGLISI 2019. Five 
new species of Henckelia (Gesneriaceae) from Myanmar and Thailand. Thai Forest Bulletin (Botany) 47(1): 3854. https://doi.org/10.20531/tfb.2019.47.1.08

WANG W.T. 1984. A new genus of Gesneriaceae from Yunnan. Acta Botanica Yunnanica 6(4): 397-401.

WANG W.T., PAN K.Y., LI Z.Y., WEITZMAN A.L. \& L.E. SKOG 1998. Gesneriaceae. In: WU Z.Y. \& P.H. RAVEN (eds.), Flora of China, Volume 18. Science Press, Beijing and Missouri Botanical Garden Press, St. Louis. pp. 244-401.

WEBER A. \& B.L. BURTT 1998[“1997”]. Remodelling of Didymocarpus and associated genera (Gesneriaceae). Beiträge Biologie der Pflanzen 70(2-3): 293-363.
WEBER A., MIDDLETON D.J., FORREST A., KIEW R., LIM C.L., RAFIDAH A., YAO T.L., SONTAG S., TRIBOUN P., WEI Y.G., YAO T.L. \& M. MÖLLER 2011. Molecular systematics and remodelling of Chirita and associated genera (Gesneriaceae). Taxon 60(3): 767790. https://doi.org/10.1002/tax.603012

WOOD D. 1974. A revision of Chirita (Gesneriaceae). Notes from the Royal Botanic Garden Edinburgh 33(1): 123-205.

YANG B., DING H.B., FU K.C., YUAN Y.K., YANG H.Y., LI J.W., ZHANG L.X. \& Y.H. TAN 2019. Four new species of Gesneriaceae from Yunnan, Southwest China. PhytoKeys 130: 183-203. https:// doi.org/10.3897/phytokeys.130.34001 